\title{
Study on Variability in Greengram (Vigna radiata L.) Genotypes
}

\author{
M. Pandiyan*, A. Krishnaveni, P. Sivakumar , C. Sivakumar, M. Vaithilingan, \\ E. Jamuna, V. Radhakrishnan, B. Sivakumar, M. Sivaji, M. Yuvaraj and V. Arunkumar
}

Agricultural College Research Institute, Tamil Nadu Agricultural University

Vazhavachanur - 606 753, Thiruvannamalai, Tamil Nadu, India

*Corresponding author

\section{A B S T R A C T}

\begin{tabular}{|l|}
\hline Key w or d s \\
Greengram, \\
Variability, \\
Phenotypic \\
Variability, \\
Genotypic \\
variability \\
\hline Article Info \\
\hline Accepted: \\
30 May 2020 \\
Available Online: \\
10 June 2020 \\
\hline
\end{tabular}

Greengram (Vigna radiata (L.) Wilczek) is legume crop cultivating throughout the year, which is amicable for all kinds of environment. The MYMV incidence and low harvest index leading to low yield. Genetic variability parameters were studied in 100 greengram genotypes raised during kharif 2013 in randomised block design with two replications. Observations were made for eighteen biometrical traits. The estimates of PCV (Phenotypic coefficient varience) were higher than GCV (Genotypic coefficient variance) for all the characters. The maximum phenotypic and genotypic variance was observed for the character dry matter production and length of branch. The estimates of phenotypic and genotypic co efficient revealed that maximum variation in dry matter production and number of clusters per branch respectively. The maximum heritability estimate was registered in maturity related trait days to full maturity (97.85), For morphological traits namely plant height (81.32) was high. The protein content recorded heritability was medium. The lowest heritability of percent was registered for dry matter production. The genetic advance for the trait plant height is high. The highest genetic advance expressed as percentage of mean was recorded by number of clusters per branch These characters were consider for parental use to create new variation for the future generation.

\section{Introduction}

Vigna radiata (L.) wilczek, commonly known as greengram or mungbean or pasipayaru in Tamil. It is one of the predominant sources of protein which gives essential amino acids in vegetarian diets. It possessed certain added features compared to other pulses. It is relatively drought tolerant and well adapted to a range of soil conditions including light soils and can thrive even under limited irrigation.
Presently, the yield level of greengram as like other pulses is well below. The management factors the prime cause for the low productivity can be ascribed to the inherently low yielding potential of the cultivars coupled with susceptibility to diseases.

To create variability for succeeding the generation by crossing of dissimilar parents and to obtain better parents for future use is very important to increase the yield of green gram. 


\section{Materials and Methods}

More number of genotypes taken for the experiments for assessing characters to see the PCV, GCV, Heritability and Genetic advance. To assess the variability in the germplasm accession collected. To evaluate and characterize genotypes for yield and yield components. The data on 18 quantitative traits for 100 accessions of greengram were raised in Agricultural Research Station, Virinjipuram Vellore in RBD. The spacing adapted for this genotype was $50 \times 20 \mathrm{~cm}$ with three replications.

Phenotypic variance $=\quad \sigma_{\mathrm{ph}}^{2}=\sigma_{\mathrm{g}}^{2}+\sigma_{\mathrm{e}}^{2}$

The co-efficient of variation was worked out by the formula of Burton (1952)

$$
\begin{aligned}
& \text { PCV }= \begin{array}{c}
(\text { Phenotypic variance })^{1 / 2} \\
\text { General mean }
\end{array} \\
& \text { GCV }={\text { (Genotypic variance })^{1 / 2}}^{-----} \text {x } 100 \\
& \quad \text { General mean }
\end{aligned}
$$

Heritability percent $=\frac{\text { Genotypic variance }}{\text { Phenotypic variance }}$

Genetic advance $=\mathrm{kx} \mathrm{h}^{2} \times \sigma_{\mathrm{ph}}$

Genetic advance (GA) as percentage of mean was also calculated.

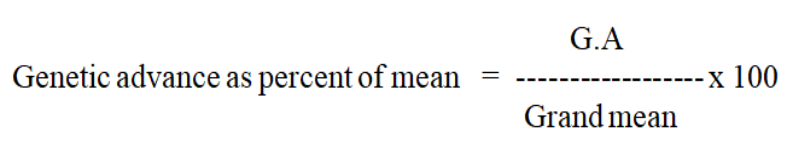

\section{Results and Discussion}

One hundred greengram genotypes used for genetic variability parameters like PCV, $\mathrm{GCV}$, Co-efficient of variation for PCV and
GCV, Heritability, Genetic advance, Genetic Advance percentage of mean were studied for 18 quantitative traits. Analysis of variance for 18 traits involving 100 accessions were showed significant differences among the genotypes for all the characters except seed length and seed breadth (Table 1). The maximum phenotypic variance was observed for the character dry matter production (210.96) followed by number of pods per plant (124.20), length of branches (200.63) and plant height (180.87).

The minimum phenotypic variance was observed for the characters namely seed length and seed breadth (Table 1). The maximum genotypic variance was observed for the character length of branch (152.33) followed by plant height (146.90) while the minimum genotypic variance was observed in the characters like seed length and seed breadth $(0.00)$ (Table 1$)$. The variability for eighteen characters, on the basis of phenotypic and genotypic coefficient of variances is furnished in Table 1.

The estimates of phenotypic co efficient revealed that maximum variation was observed in dry matter production (67.69) followed by number of clusters per branch (61.23) and single plant yield (51.74). The least phenotypic co efficient of variation was observed for the trait days to full maturity (6.17) (Table 1) while the genotypic co efficient of variation was maximum for the character number of clusters per branch (47.71) followed by single plant yield (41.86) and length of branch (40.20). The lowest genotypic co efficient of variation observed for the character was number of seeds per pod (4.85) (Table 1). Estimates of heritability in the broad sense, genetic advance and genetic advance as percentage of mean are furnished in Table 1. The maximum heritability estimate was registered by maturity related traits namely days to full maturity (97.85), 
days to initial flowering (97.43), days to initial maturity (97.43) and days to fifty per cent flowering (97.17). The heritability estimates for seed dimension traits namely seed length (96.13), seed breadth (95.15) were also higher.

For morphological traits namely plant height (81.32), length of branch (74.58), hundred seed weight (74.58), length of pod (72.39), number of clusters per plant (66.84), single plant yield (65.05), number of pods per plant (63.44), number of clusters per branch (60.29), number of branches per plant (57.54) and number of seeds per pod (35.00) were high to medium while for protein content (45.15) heritability was medium.

The lowest heritability of (20.65) percent was registered for dry matter production (Table 1). The genetic advance of the characters ranged from 0.09 to 21.57 for the traits seed breadth and plant height respectively. The highest genetic advance expressed as percentage of mean was recorded by number of clusters per branch (77.54) followed by length of branch (72.47) and single plant yield (70.73) while the lowest genetic advance as percentage of mean was recorded for number of seeds per pod (5.99) (Table 1).

The present investigation included the following aspects as follows Studies on variability of different germplasm collected genotypes for assessment of their breeding value. The estimates of variability parameters namely PCV and GCV were higher for the traits namely single plant yield, number of branches per plant, number of pods per plant, number of clusters per plant, plant height and length of branch indicating that the scope of selection for these traits was high. The traits, dry matter production and number of cluster per branch revealed wide differences between the estimates of PCV and GCV values indicating high influence of environmental factors while the traits, days to initial flowering, days to 50 per cent flowering, days to initial maturity, days to full maturity, hundred seed weight, seed length, seed breadth, length of pod and protein content were found less influenced by the environmental factors as the difference between the estimates of PCV and GCV were narrow.

Similar results were also reported (Khan, 1984; Malik and Singh, 1983; Renganayaki, 1985; Reddy, 1997 and Venkateswarlu, 2001). The wide difference between the GCV and PCV for the characters viz., dry matter production and number of clusters per branch observed in this investigation were in accordance with the findings (Chandra and Nijhawa, 1979; Malik and Singh, 1983; Renganayaki, 1985; Reddy, 1997 and Venkateswarlu, 2001) indicating that the expression of these traits were masked by environmental components.

For the characters plant height, length of branch, days to initial flowering, days to 50 per cent flowering, days to initial maturity, days to full maturity, hundred seed weight , seed length, seed breadth, length of pod and number of clusters per plant, differences between GCV and PCV were narrow suggesting that these characters were less influenced by environmental fluctuation and similar results were reported (Malik and Singh, 1983; Jain, 1975; Renganayaki, 1985; Reddy, 1997; Venkateswarlu, 2001; Chakrabarty and Parimal Barman, 2003).

As these traits are environmentally stable, the scope for direct selection is high. Maturity related traits viz., days to initial flowering, days to 50 per cent flowering, days to initial maturity, days to full maturity followed by seed dimension characters like seed length, seed breadth and morphological characters like plant height, length of branch, hundred seed weight and length of pods recorded high heritability values as reported (Singh and 
Malhotra 1970), (Mansuriya 1991), (Sharma 1999), (Malik and Singh 1983), (Dahiya and Yadav 1999), (Renganayaki 1985), (Venkateswarlu 2001) and (Ruiz de Galarreta and Alvarez 2001).

According to Burton (1952), a character having high value of GCV coupled with high heritability would be more valuable in selection programmes. The characters viz., single plant yield, number of clusters per branch, number of pods per plant, length of branch, plant height, number of cluster plant and number of branches per plant showed high GCV with high heritability indicating less influence of environment on the characters and high transmission index.

This results were in accordance with the findings (Malhotra et al., 1974 a, b; Chandal et al., 1973; Malik and Singh, 1983; Renganayaki, 1985; Khorgade et al., 1990; Ganeshram, 1993; Reddy, 1997; Venkateswarlu, 2001; Tefera et al., 1990 and Taddesse, 1993).

High genetic advance as percentage of mean observed for the traits, number of clusters per branch, length of branch, single plant yield, number of pods per plant, number of clusters per plant, plant height and number of branches per plant suggesting scope for selection for these traits in the core collection.

High genetic advance coupled with high heritability and GCV was observed for length of branch, number of clusters per branch, number of clusters per plant, number of pods per plant, single plant yield and plant height indicating the predominance of additive gene action for these traits. Johnson et al., (1955) suggested that the heritability and genetic advance when calculated together would be more useful in predicting the effectiveness of the character for improvement. High genetic advance as per cent of mean together with high heritability and GCV was noted for length of branch, number of clusters per branch, number of clusters per plant, number of pods per plant and single plant yield. This indicated the preponderance of additive gene action.

High heritability and genetic advance were also reported (Rathinasamy et al., 1978), (Malik and Singh,1983), (Renganayaki,1985), (Ganesh Ram 1993), (Reddy 1997) and Venkateswarlu (2001) for plant height, length of pod, number of clusters per plant and number of pods per plant. For number of branches per plant high heritability and genetic advance values were reported by Renganayaki (1985), Ganesh Ram (1993) and Reddy (1997).

Therefore, simple unidirectional selection could be effective for improving the aforesaid traits. Relatively lower magnitude of genetic advance and GCV and moderate value of heritability for protein content, number of branches per plant and number of seeds per pod indicated that these characters were under the control of non-additive gene effects. Similar findings in mungbean were reported (Raje and Rao, 2000).

Improvement for such important characters would have to be carried out by indirect selection method as suggested (Rajendrakumar et al., 1999) and (Vikas et al., 1999). By estimating PCV and GCV both it is useful to determine the amount of variation that is heritable. Heritability is an index for the transmission of characters from parents to offspring. Genetic advance is the genetic gain under selection. The estimates of heritability were environment specific (Shimelis and Rhandzu, 2010). 
Table.1 Mean, variance, co efficient of variation, heritability (broad sense), genetic advance, and genetic advances as per cent of mean for 18 characters of 100 greengram accessions

\begin{tabular}{|c|c|c|c|c|c|c|c|c|}
\hline \multirow[t]{2}{*}{ Character } & \multirow[t]{2}{*}{ Mean } & \multicolumn{2}{|c|}{ Variance } & \multicolumn{2}{|c|}{$\begin{array}{c}\text { Co efficient of } \\
\text { variation }\end{array}$} & \multirow[t]{2}{*}{$\begin{array}{c}\text { Herita } \\
\text { bility }\end{array}$} & \multirow[t]{2}{*}{$\begin{array}{l}\text { Genetic } \\
\text { advance }\end{array}$} & \multirow{2}{*}{$\begin{array}{c}\text { Genetic } \\
\text { advance } \\
\% \text { of } \\
\text { mean }\end{array}$} \\
\hline & & $\begin{array}{l}\text { Geno } \\
\text { typic }\end{array}$ & $\begin{array}{c}\text { Pheno } \\
\text { typic }\end{array}$ & $\begin{array}{c}\text { Geno } \\
\text { typic } \\
\%\end{array}$ & $\begin{array}{c}\text { Pheno } \\
\text { typic } \\
\%\end{array}$ & & & \\
\hline PHT (cm) & 51.55 & 146.90 & 180.87 & 23.60 & 26.16 & 81.32 & 21.57 & 42.86 \\
\hline NOB & 1.95 & 0.29 & 0.48 & 25.99 & 35.29 & 57.54 & 0.85 & 41.55 \\
\hline BRL (cm) & 29.22 & 152.33 & 200.63 & 40.20 & 47.14 & 74.58 & 21.19 & 72.47 \\
\hline DIF & 36.60 & 15.66 & 15.87 & 10.87 & 10.94 & 97.74 & 8.36 & 21.23 \\
\hline DFF & 43.27 & 15.88 & 16.20 & 9.29 & 9.38 & 97.17 & 8.40 & 17.95 \\
\hline NCB & 4.55 & 3.99 & 7.96 & 47.71 & 61.23 & 60.29 & 3.57 & 77.54 \\
\hline NOC & 11.31 & 8.79 & 13.35 & 30.30 & 36.79 & 66.84 & 5.30 & 50.40 \\
\hline NPP & 27.50 & 79.65 & 124.20 & 30.54 & 39.29 & 63.44 & 13.87 & 51.15 \\
\hline POL (cm) & 7.50 & 0.37 & 0.49 & 7.93 & 9.26 & 72.39 & 1.08 & 13.99 \\
\hline NSP & 10.43 & 0.32 & 0.96 & 4.85 & 8.07 & 35.00 & 0.70 & 5.99 \\
\hline SDL (cm) & 0.39 & 0.00 & 0.00 & 10.99 & 12.17 & 96.13 & 0.10 & 23.32 \\
\hline SDB (cm) & 0.32 & 0.00 & 0.00 & 11.13 & 12.37 & 95.15 & 0.09 & 23.49 \\
\hline HSW (g) & 3.25 & 0.40 & 0.54 & 18.04 & 20.91 & 73.33 & 1.12 & 30.99 \\
\hline SPY (g) & 4.98 & 5.99 & 8.99 & 41.86 & 51.74 & 65.05 & 4.17 & 70.73 \\
\hline DMP (g) & 20.22 & 44.85 & 210.96 & 30.94 & 67.69 & 20.65 & 6.50 & 29.60 \\
\hline PTC (\%) & 19.40 & 1.45 & 3.13 & 5.90 & 8.68 & 45.15 & 1.69 & 8.25 \\
\hline DIM & 55.67 & 15.07 & 17.35 & 7.09 & 7.15 & 97.43 & 8.21 & 13.48 \\
\hline DFM & 68.12 & 16.88 & 17.11 & 6.13 & 6.17 & 97.85 & 8.67 & 11.53 \\
\hline
\end{tabular}

PHT - Plant Height,NOB - No. of Branches (cm) -Branch Length, IF - Day for flower initiation,

DFF Day for flower formation - No. of cluster per branch, NOC - No of Cluster -Pod length, NSP- No. of seeds per pod, SDL - seed length, SDB -Seed diameter, SW - Hundred seed weight, DMP - Dry matter production

The selection based on the heritability alone is create confusion for selection for traits when its combined with genetic advance as percent of mean is of great importance (Mehandi et al., 2013). Genotypes exhibiting high mean value for yield and its component traits could be employed as parents for the development of high yielding varieties.

\section{References}

Chakrabarty, SK and Parimal Barman.2003. Phenotypic variability and characters association in greengram (Vigna radiata L. Wilczek). Environ and Ecol., 21 (1):
$174-178$.

Chandel, KPS, Joshi, BS and Pant, KC. 1973. Yield in mung bean and its components. Indian J. Genet., 33: 271-276.

Dahiya, BN and Yadav, OP. 1999. Evaluation and characterization of promising genotypes of greengram (Vigna radiata (L.) Wilczek). Annals Agri. Bio. Res., 4(1): 59-62.

Doku, J.L. 970. Variability in local and exotic varieties of cowpea (Vigna unguiculata (L.) Walp) in Ghana. Ghana J. Agric. Sci., 3: 139-143.

Ganeshram, S. 1993. Evaluation of some genotype's interspecific hybrids and 
derivatives of greengram ( $V$. radiata (L.) Wilczek $\mathrm{x}$ Black gram (Vigna mungo (L.) Hepper) crosses. M.Sc. (Ag.) Thesis, Tamil Nadu Agricultural University, Coimbatore.

Hemavathy, A. Shanmugavalli, N. and Anand, G. 2015. Genetic variability, correlation and path co-efficient studies on yield and its components in mungbean [Vigna radiata (L.) Wilczek]. Legume Res., 38(4): 442-446.

Khan, IA.1984. Estimates of genetic variability in mutated populations of mungbean (Vigna radiata L. Wilczek). Legume Res., 7 (1) 57 - 58.

Khorgade, PW, Nafade, AH, Naikhede,MN. and Raut, SK. 1990. Some selection criteria in greengram. J. Maharashtra Agric. Univ., 15 (2): 179-182.

Makeen, K., Abrahim, G., Jan, A. and Singh, AK. 2007. Genetic variability and correlations studies on yield and its components in Greengram [Vigna radiata (L.) Wilczek]. Journal of Agronomy, 6(1): 216-218.

Malhotra, VV, Sukhdevasingh and Singh, KB. 1974a. Yield components in greengram (Phaseolus aureus Roxb.). Indian J. Agric. Sci., 44: 136-41.

Malhotra, VV., Sukhdev Singh and KB. Singh. 1974b. Relation between geographic diversity and genetic divergence and the relative role of each character towards maximising divergence in greengram. Indian. $J$. Agric. Sci., 44: 811-815.

Malik, BPS, Singh, VP, Chaudhary and Chowdhary RK. 1982. Path coefficient analysis and selection indices in greengram. Indian J. Agric. Sci., 52: 288-91.

Malik, BPS. and Singh, VP. 1983. Multiple correlation and regression analysis in greengram. Indian J. Agric. Sci., 53: 400-403.

Malosetti, M. and Abadie, T. 2001. Sampling strategy to develop a core collection of Uruguayan maize landraces based on morphological traits. Genetic Resources and Crop Evolution, 48: 381 - 390.

Mansuria, CA. 1991. Genetics of quantitative traits in greengram. Mysore J. Agric. Sci., 25: 165-168.

Mehandi Suhel, Singh, CM. and Kushwaha, VK. 2013. Estimates of genetic variability and heritability for yield and yield component traits in Greengram [Vigna radiata (L.) Wilczek]. The Bioscan, 8(4): 1481-1484

Parida, D and Singh, DP. 1984. Association, heritability and genetic advance in the $\mathrm{F}_{2}$ generation of wide and varietal crosses of greengram. Madras Agric. J., 71: 351-356

Rajendra kumar, AS, Rathi, and Singh, A. 1999. Association analysis in Vigna mungo (L.). Ann. Agric.Res., 20 (4): 468 -471 .

Rao, SS, Singh, SP and Rao, SK. 1984. Estimation of additive, Dominance, Digenic Epistatic interaction effects for yield and its components in mung bean (Vigna radiata (L.) Wilczek. Legume Res., 7 (1): 6-12.

Reddy, KHP. 1997. Genetic variability in greengram (Vigna radiata (L.) Wilczek). Ann. Agric. Res., 18 (4): 554 $-554,493-497$.

Renganayaki, K. 1985. Studies on genetic differentiation between three species of Vigna Savi. M.Sc. (Ag.) Thesis, Tamil Nadu Agricultural University, Coimbatore.

Ruiz de Galarreta, JI and Alvarez, A. 2001. Morphological classification of maize land races from northern Spain. Genet Res and Crop Evol., 48: 391 - 400.

Sharma RN. 1999. Heritability and character association in non-segregating populations of mungbean (Vigna radiata (L.) Wilczek). J. of Interacademicia., 3 (1):5-10. 
Singh, K.B. and R.S. Malhotra. 1970. Estimate of genetic and environmental variability in mung bean (Phaseolus aureus Roxb.). Madras Agric. J., 57: 155-159.

Sowmini, K. and Jayamani, P. 2013. Genetic variability studies for yield and its component traits in RIL population of blackgram (Vigna mungo (L.) Hepper). Electronic J. of Plant Breeding, 4(1): 1050-1055.

Taddesse, D. 1993. Study on genetic variation of landraces of tef Eragrostic tef (Zucc.)
Trotter in Ethiopia. Genet Res. and Crop Evol., 40: 10-04.

Tefera, H, Ketema, S and Tessema, T. 1990. Variability, heritability and genetic advance in the (Eragrosis tef (Zucc.) Trotter cultivars. Trop. Agric. (Trindad)., 67: 317-320

Venkateswarlu, O. 2001b. Genetic variability in greengram (Vigna radiata (L.) Wilczek). Legume Res., 24 (1): 69 - 70.

Wilczek, R. 1954. Phaseolinae. Flora du Congo belge et du Rwanda - Urundi Bruxelles, 6: 206-409

\section{How to cite this article:}

Pandiyan, M., A. Krishnaveni, P. Sivakumar, C. Sivakumar, M. Vaithilingan, E. Jamuna, V. Radhakrishnan, B. Sivakumar, M. Sivaji, M. Yuvaraj and Arunkumar, V. 2020. Study on Variability in Greengram (Vigna radiata L.) Genotypes. Int.J.Curr.Microbiol.App.Sci. 9(06): 3868-3874. doi: https://doi.org/10.20546/ijcmas.2020.906.456 